\title{
Detection of herpes simplex virus DNA in atypical epithelial keratitis using polymerase chain reaction
}

\author{
Noriko Koizumi, Kohji Nishida, Wakako Adachi, Mamoru Tei, Yoichi Honma, \\ Atsuyoshi Dota, Chie Sotozono, Norihiko Yokoi, Shuji Yamamoto, Shigeru Kinoshita
}

\begin{abstract}
Aim-To study herpes simplex virus (HSV) DNA in tears from patients with atypical epithelial keratitis of unknown aetiology.

Methods-Tear samples were collected from 17 affected eyes of 17 consecutive patients suffering from epithelial keratitis in whom HSV keratitis was suspected but whose diagnosis was difficult on the basis of clinical manifestations alone. Using reduced sensitivity polymerase chain reaction (PCR), tear samples were tested for HSV DNA. Tears from the unaffected eyes of the 17 patients were also examined, along with 38 tear samples from 19 normal volunteers. Southern blot analysis was performed to confirm that amplified DNA bands were specific for HSV. Clinical correlation with photographs of corneal lesions was also investigated.

Results-HSV DNA was detected in tears from the affected eyes of eight of the 17 patients with suspected HSV keratitis. Tears from the affected eyes of the other patients were PCR negative, as were tears from the unaffected eyes of all 17 patients, and from the 38 normal eyes. There was no correlation between PCR results and clinical manifestation of keratitis.

Conclusions-Based on the sensitivity of the PCR system, eight of 17 suspected HSV keratitis patients were confirmed as suffering from HSV keratitis. HSV keratitis should therefore be considered as a possible diagnosis in atypical epithelial keratitis.

(Br f Ophthalmol 1999;83:957-960)
\end{abstract}

Herpes simplex virus (HSV) epithelial keratitis, a leading cause of corneal blindness, is typified by dendritic or geographical corneal ulcers, which usually have dendritic edges with terminal bulbs and epithelial infiltration. This enables them to be differentiated from corneal ulcers due to other causes, and their clinical diagnosis as herpetic keratitis. Sometimes, however, such factors as duration since onset, previous medication, systemic diseases (atopic dermatitis, ${ }^{1}$ for example), or history of corneal transplantation $^{2}$ can make the epithelial lesions appear different from classic HSV lesions. The initial diagnosis is very important, since it decides the use of antiviral drugs, such as aciclovir. In atypical cases, however, it is often difficult to make a correct diagnosis based solely on the clinical presentation.
Since Saiki et al's 1985 report on the usefulness of the polymerase chain reaction (PCR) for diagnostic purposes, ${ }^{3}$ it has often been used for diagnosing viral diseases of the eye. ${ }^{4-22}$ Previously, we established a reduced sensitivity PCR for diagnosing HSV epithelial keratitis, ${ }^{4-7}$ corneal endothelitis, ${ }^{8}$ and HSV related uveitis. ${ }^{9}{ }^{10}$ Using this PCR system, we are able to detect HSV DNA in tears from patients with clinically diagnosed HSV epithelial keratitis. The sensitivity of this system is higher than that of viral culture, while being low enough not to give a positive PCR result in normal tears. ${ }^{45}$

In the present study, we used the reduced sensitivity PCR system to investigate HSV DNA in tears from suspected epithelial keratitis patients in whom a clear diagnosis was difficult on the basis of clinical presentation alone.

\section{Subjects and methods}

SUBJECTS

At our hospital, if we cannot easily diagnose a patient as having herpetic keratitis on the basis of clinical manifestations alone, we perform a PCR assay on tears to search for HSV (see below). In the present study we performed PCR for HSV DNA on tears from 17 consecutive patients who visited our hospital over a 22 month period (August 1994 to May 1996). All had unusually shaped epithelial defects or ulcers, and the aetiology could not be easily diagnosed.

To ensure that these cases were not typical herpetic epithelial keratitis (and were not clearly another disease), two anterior segment photographs (one diffuse light photograph and one fluorescein stained photograph (Fig 1)) were shown to 14 ophthalmologists (with diploma in ophthalmology recognised in Japan), who were asked whether they thought the lesions were herpetic keratitis.

POLYMERASE CHAIN REACTION

With proper informed consent, we performed PCR to amplify and detect HSV DNA in tears taken from the 17 affected eyes of the suspected HSV keratitis patients, along with tears from their unaffected contralateral eyes and tears from 38 eyes of 19 healthy volunteers. Sample collection and PCR testing were performed in accordance with our previous report. ${ }^{45}$ We had confirmed that the method was sufficiently sensitive to detect HSV DNA in eyes with clinically diagnosed herpetic keratitis or conjunctivitis, and reliable enough not to give false positive results in normal subjects. ${ }^{4}$

In brief, tear samples were collected by placing Schirmer's strips on the inferior temporal
Accepted for publication 26 April 1999 


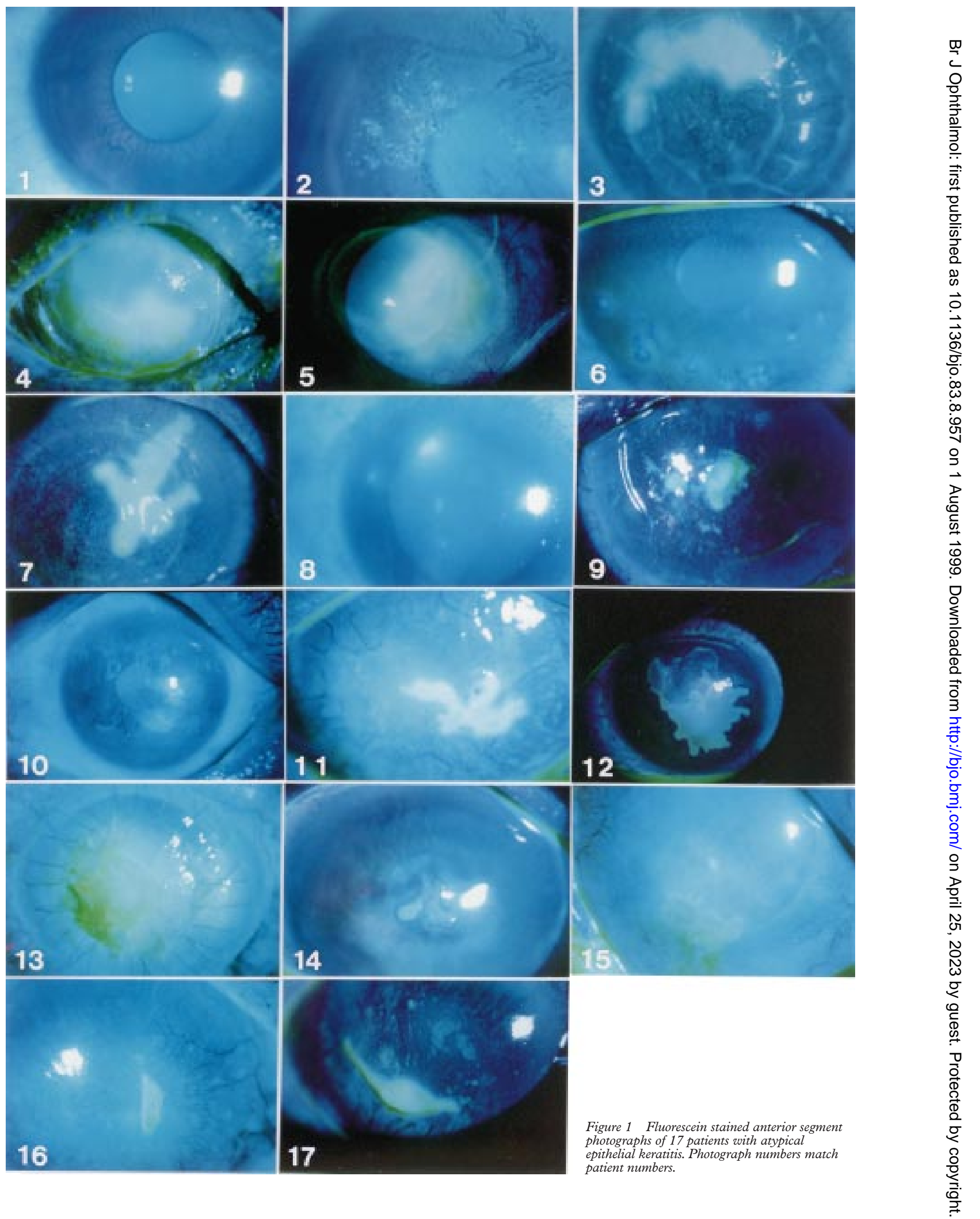


Table 1 Summarised data of study group

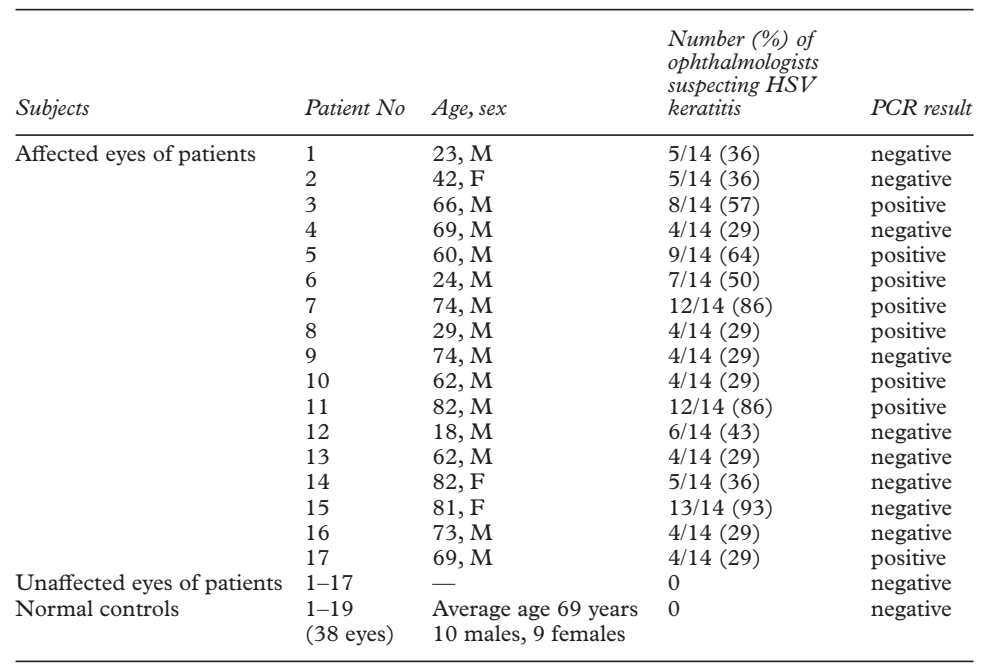

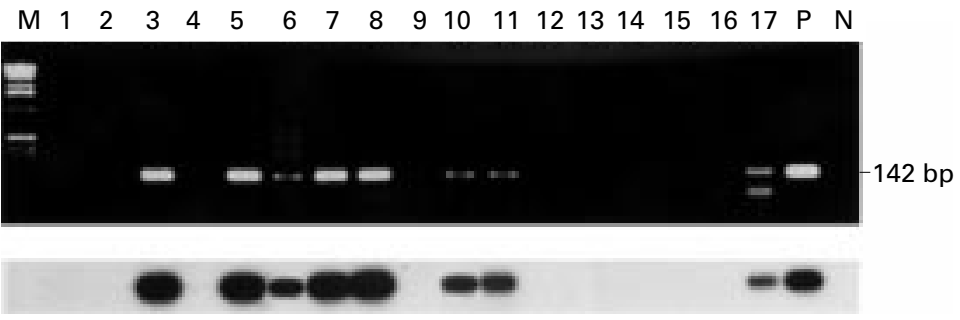

Figure 2 Detection of herpes simplex virus DNA in tear samples. (Top) Agarose gel electrophoresis of PCR products. Lanes 1-17 represent tears from 17 eyes of atypical

epithelial keratitis patients. $P=$ positive control; $N=$ negative control. Patient Nos 3, 5, 6, 7, 8, 10,11, 17 showed $142 \mathrm{bp}$ amplified bands. (Bottom) Southern blot hybridisation confirms results of agarose gel electrophoresis. Lanes 1-P are same as those at the top.

cul de sac for 5 minutes. Each strip, when wet to at least $5 \mathrm{~mm}$ in length, was placed in a microtube containing $100 \mu \mathrm{l}$ of distilled water, and vortexed. To this was added $100 \mu \mathrm{g} / \mathrm{ml}$ of proteinase $\mathrm{K}$ and $0.5 \%$ sodium dodecyl sulphate, $1 \mathrm{mM}$ of ethylenediamine-tetraacetic acid (EDTA), and $10 \mathrm{mM}$ of TRIShydrochloride ( $\mathrm{pH} 7.8)$, giving a final reaction volume of $500 \mu \mathrm{l}$. The solution was incubated at $55^{\circ} \mathrm{C}$ for 3 hours, then extracted by phenol chloroform. After glycogen was added as a carrier, the DNA was precipitated with ethanol and dissolved in $10 \mu \mathrm{l}$ of distilled water.

The PCR reaction for each sample included $1 \mu l$ of DNA and $24 \mu \mathrm{l}$ of PCR reaction buffer (10 mM TRIS-hydrochloride ( $\mathrm{pH}$ 8.3), 50 $\mathrm{mM}$ potassium chloride, $1.5 \mathrm{mM}$ magnesium chloride, $0.01 \%$ gelatin) in the presence of 80 $\mu \mathrm{M}$ each of all four triphosphates, 5 pmol each of oligonucleotide primer, and $1.25 \mathrm{U}$ Taq DNA polymerase. The pair of primers used bracketed a 142 base pair segment of the DNA polymerase gene of the HSV genome ${ }^{23}$ (5'ATCCGAACGCAGCCCCGCTG， 5-TCT CCGTCCAGTCGTTTATCTTC). After layering with $50 \mu$ of mineral oil, the mixture was placed in a thermal cycler (Cetus, PerkinElmer, Norwalk, CT, USA) and heated for 1 minute at $94^{\circ} \mathrm{C}$ for denaturation, cooled for 1 minute at $55^{\circ} \mathrm{C}$ for annealing, and incubated for 1 minute at $72^{\circ} \mathrm{C}$ for extension. This cycle was repeated 30 times.

After DNA amplification, $7 \mu$ l of each sample was electrophoresed on ethidium bro-

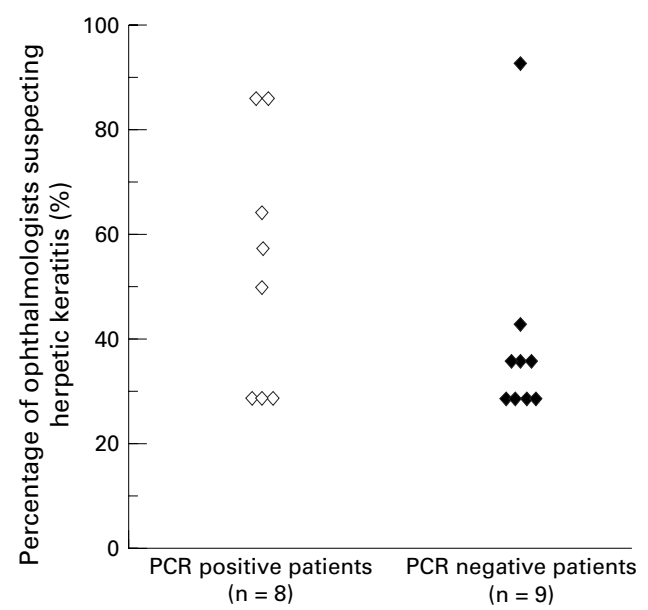

Figure 3 Distribution of percentages of 14 ophthalmologists suspecting herpetic keratitis in PCR positive and negative patients. Each lozenge matches one patient.

mide stained $1.5 \%$ agarose gel at $100 \mathrm{mV}$. To confirm that the amplified bands were specific for HSV, we performed Southern blot hybridisation using a ${ }^{32} \mathrm{P}$ labelled oligonucleotide probe specific for the amplified DNA (5'GCGTTTGAGACCGCCGGCACGTACCT GCGGCT-3').

The $t$ test was used to detect any difference in percentage of ophthalmologists suspecting HSV keratitis in the PCR positive (that is, HSV DNA detected) group, compared with the PCR negative (that is, HSV DNA not detected) group.

\section{Results}

HSV DNA was detected by PCR in eight of the affected eyes of the 17 patients, but in none of the unaffected eyes, nor in any of the 38 eyes of the 19 normal subjects (Table 1; Fig 2). These results were confirmed by Southern blot hybridisation. In the 17 patients, the percentage of ophthalmologists who suspected that the corneal lesions represented herpetic keratitis varied considerably (Table 1 ).

There was no statistically significant difference $(p=0.220)$ between PCR positive and PCR negative patients as regards the percentage of ophthalmologists who diagnosed HSV keratitis (Fig 3).

\section{Discussion}

In recent years, we have demonstrated the use of a diagnostic PCR strategy ${ }^{45}$ and have reported its clinical use in the diagnosis of herpetic keratitis, ${ }^{4-7}$ corneal endothelitis, ${ }^{8}$ and uveitis. $^{910}$ These previous studies employed a reduced sensitivity PCR assay which is approximately 100 times less sensitive than the method used by Boerman and associates in their work on HSV in small volumes of cerebrospinal fluid. ${ }^{24}$ In our 1994 report describing the use of this reduced sensitivity PCR system, we reported that we had never detected HSV DNA in tear samples taken from normal subjects, but were able to successfully detect HSV DNA in tears from $100 \%$ of patients examined who had been clinically diagnosed with HSV epithelial keratitis. ${ }^{4}$ 
Moreover, even though its sensitivity is reduced, this PCR system is more sensitive than a viral culture system. ${ }^{4}$

In the present study, we used the reduced sensitivity PCR system to investigate HSV DNA in tear samples from 17 consecutive patients with unusual epithelial defects or ulcers that led us to suspect HSV keratitis but which made definitive clinical diagnosis difficult. The results showed that none of the tears from the 17 contralateral unaffected eyes of the suspected HSV keratitis patients was positive for HSV; nor were the tears from 38 normal eyes. However, of the 17 affected eyes of 17 patients with suspected epithelial keratitis examined, HSV DNA was present in almost half (eight of 17). Although viral culture was not performed, on the basis of our PCR sensitivity the eight PCR positive eyes are strongly suspected of having HSV keratitis.

For the purposes of this study, we defined atypical epithelial keratitis as a condition characterised by the presence of unusually shaped defects or ulcers in the cornea, and in which characteristic HSV keratitis findings, such as dendritic or geographical ulcers with terminal bulbs and epithelial infiltrations, are not evident. When we showed clinical photographs to 14 ophthalmologists and asked for a diagnosis, we found little correlation $(p=0.220)$ between the PCR results (positive or negative) and the ophthalmologists' diagnosis.

The present study, using our reduced PCR system, indicates that some cases of atypical keratitis are in fact HSV keratitis; HSV epithelial keratitis should therefore be considered in cases of atypical epithelial keratitis.

Presented at the Association for Research in Vision and Ophthalmology meeting, 12 May 1998, Fort Lauderdale, FL, USA.

Supported in part by a research grant (40244610) from the Ministry of Education, a grant from the Kyoto Foundation for the Promotion of Medical Science, and the Intramural Research Fund of the Kyoto Prefectural University of Medicine.

1 Wilhelmus KR, Falcon MG, Jones BR. Bilateral herpetic keratitis. Br F Ophthalmol 1981;65:385-7.

2 Beyer CF, Arens MQ, Hill JM, et al. Penetrating keratoplasty in rabbits induces latent HSV-1 reactivation when corticosteroids are used. Curr Eye Res 1989;8:1323-9.

3 Saiki RK, Scharf S, Faloona F, et al. Enzymatic amplification of $\beta$-globin genomic sequences and restriction site analysis for diagnosis of sickle cell anemia. Science 1985;230:1350-4. Yamamoto S, Shimomura Y, Kinoshita S, et al. Detection of polymerase chain reaction. Am $\mathcal{f}$ Ophthalmol 1994;117: polymeras.
5 Soma H, Nishida K, Adachi W, et al. Detection sensitivity of herpes simplex virus DNA in tear fluid by PCR method. fpn f Clin Ophthalmol 1995;49:603-6.

6 Yamamoto S, Shimomura Y, Kinoshita S, et al. Differentiating zosteriform herpes simplex from ophthalmic zoster. Arch Ophthalmol 1994;112:1515-6.

7 Tei M, Nishida K, Kinoshita S. Polymerase chain reaction detection of herpes simplex virus in tear fluid from atypical herpetic epithelial keratitis after penetrating keratoplasty. Am f Ophthalmol 1996;122:732-5.

8 Ohashi Y, Yamamoto S, Nishida K, et al. Demonstration of herpes simplex virus DNA in idiopathic corneal endotheliopathy. Am f Ophthalmol 1991;112:419-23.

9 Yamamoto S, Pavan-Langston D, Kinoshita S, et al. Detecting herpesvirus DNA in uveitis using the polymerase chain reaction. Br f Ophthalmol 1994;80:465-8.

10 Yamamoto S, Pavan-Langston D, Tada R, et al. Possible role of herpes simplex virus in the origin of Posner-Schlossman syndrome. Am f Ophthalmol 1995;119:796-8.

11 Fox GM, Crouse CA, Chuang EL, et al. Detection of herpesvirus DNA in vitreous and aqueous specimens by the polymerase chain reaction. Arch Ophthalmol 1991;109: 266-71.

12 Nishi M, Hanashiro R, Mori S, et al. Polymerase chain reaction for the detection of the varicella-zoster genome in ocular samples from patients with acute retinal necrosis. $A m \mathcal{F}$ Ophthalmol 1992;114:603-9.

13 Usui $M$, Usui N, Goto $H$, et al. Polymerase chain reaction for diagnosis of herpetic intraocular inflammation. Ocular Immunol Inflamm 1993;1:105-12.

14 Garweg J, Fenner T, Böhnke M, et al. An improved technique for the diagnosis of viral retinitis from samples of aqueous humor and vitreous. Graefes Arch Clin Exp Ophthalmol 1993;231:508-13.

$15 \mathrm{Yu}$ DD, Lemp MA, Mathers WD, et al. Detection of varicella-zoster virus DNA in disciform keratitis using polymerase chain reaction. Arch Ophthalmol 1993;111: 167-8.

16 Mitchell SM, Fox JD, Tedder RS, et al. Vitreous fluid sampling and viral genome detection for the diagnosis of viral retinitis in patients with AIDS. F Med Virol 1994;43:33640.

17 Alvarado JA, Underwood JL, Green WR, et al. Detection of herpes simplex viral DNA in the iridocorneal endothelial syndrome. Arch Ophthalmol 1994;112:1601-9.

18 Kumano Y, Manabe J, Hamamoto M, et al. Detection of varicella-zoster virus genome having a PSTI site in the ocular sample from a patient with acute retinal necrosis. Ophthalmic Res 1995;27:310-6.

19 De Boer JH, Verhagen C, Bruinenberg M, et al. Serologic and polymerase chain reaction analysis of intraocular fluids in the diagnosis of infectious uveitis. Am $\mathcal{F}$ Ophthalmol 1996;121:650-8.

20 Cunningham ET Jr, Short GA, Irvine AR, et al. Acquired immunodeficiency syndrome-associated herpes simplex virus retinitis. Clinical description and use of a polymerase chain reaction-based assay as a diagnostic tool. Arch Ophthalmol 1996;114:834-40.

21 Rahhal FM, Siegel LM, Russak V, et al. Clinicopathologic correlations in acute retinal necrosis caused by herpes simplex virus type 2. Arch Ophthalmol 1996;114:1416-9.

22 Cockerham GC, Krafft AE, McLean IW. Herpes simplex virus in primary graft failure. Arch Ophthalmol 1997;115: 586-9.

23 Powell KF, Anderson NE, Frith RW, et al. Non-invasive diagnosis of herpes simplex encephalitis. Lancet 1990;335: 357-8.

24 Boerman RH, Arnoldus EPJ, Raap AK, et al. Polymerase chain reaction and viral culture techniques to detect HSV in small volumes of cerebrospinal fluid; an experimental mouse encephalitis study. F Virol Methods 1989;25:18998. 